\title{
Different trace mineral sources and recommendations in the performance and quality of eggs from Dekalb White layers
}

\author{
Gabrielle Catarine Castro Pereira ${ }^{1}$, Fernando Guilherme Perazzo Costa ${ }^{1}$, José Humberto \\ Vilar da Silva1', Leonardo Augusto Fonseca Pascoal ${ }^{1}$, Cristina Aparecida Barbosa de Lima', \\ Letícia Cardoso Bittencourt ${ }^{2 *}$, Alexandre da Silva Sechinato ${ }^{2}$, Rafael Gustavo Hermes ${ }^{2}$ \\ ${ }^{1}$ Universidade Federal da Paraíba, Areia, PB, Brasil. \\ ${ }^{2}$ DSM Produtos Nutricionais Brasil S.A, São Paulo, SP, Brasil.
}

\begin{abstract}
This work aimed to evaluate the performance and egg quality of lightweight laying hens supplemented with a high biological value mineral, carbo-amino-phospho-chelates (CAPC), compared with inorganic minerals (sulfates), at different recommended values. A total of 320 Dekalb White hens, between 53 and 77 weeks of age, were distributed in a completely randomized design into two treatments, 10 replicates of 16 birds each. The treatments consisted of a reference diet formulated according to breed manual recommendations, in which one group was supplemented with a trace mineral source, $\mathrm{CAPC}(\mathrm{Cu}, 8.6$; $\mathrm{Fe}, 43.7 ; \mathrm{Mn}, 56.4$; Se, 0.34; and $\mathrm{Zn}, 43.7 \mathrm{mg} / \mathrm{kg}$ ) and the other with a sulfate source, using the levels recommended in the breed manual ( $\mathrm{Cu}, 8 ; \mathrm{Fe}, 60 ; \mathrm{Mn}, 70 ; \mathrm{Se}, 0.25 ;$ and $\mathrm{Zn}, 60 \mathrm{mg} / \mathrm{kg})$. There was no effect of trace mineral supplementation on egg production variables, feed conversion ratio by mass or by dozen eggs, and eggs per housed bird. However, there was an increase in feed intake and weight and mass of eggs when birds fed diet supplemented with CAPC. Regarding egg quality, CAPC supplementation increased the albumen weight and percentage, shell weight, thickness, and strength, and Haugh unit. The eggs from birds fed CAPC supplementation showed higher levels of iron and zinc when compared with eggs from birds fed the sulfate source diet. Better quality rates were observed in variables related to shelf life for the group that received CAPC. Trace mineral sources and recommendations in the diets of high genetic potential laying hens need to be reassessed and allow us to conclude that totally replacing the sulfate for different recommendations of CAPC in laying hen diets helps to improve quality characteristics as well as the nutritional value of eggs.
\end{abstract}

Key Words: albumen, carbo-amino-phospho-chelates, egg shell, trace minerals, shelf life

\section{Introduction}

Microelements are involved in numerous metabolic functions and are essential for the normal growth of living organisms because they act as catalysts or enzymatic components of many cells (Świątkiewicz et al., 2014). Due to their importance in various metabolic processes, in practice, these elements are added in high quantities to poultry diets, which can lead to a high concentration of microelements in the animal body and, consequently, higher excretion and accumulation in the environment, especially in areas with intensive poultry production. For example, in the production of broilers, it was found that $94 \%$ of the ingested zinc was excreted in the environment (Mohanna and Nys, 1997). For

Received: September 18, 2017

Accepted: December 5, 2017

*Corresponding author: leticia.cardoso@dsm.com

Copyright (C) 2018 Sociedade Brasileira de Zootecnia. This is an Open Access article distributed under the terms of the Creative Commons Attribution License (http://creativecommons.org/licenses/by/4.0/), which permits unrestricted use, distribution, and reproduction in any medium, provided the original work is properly cited. this reason, more bioavailable sources of trace minerals have been developed and are available in the market, so that they can be added to the diet of laying hens at smaller quantities when compared with inorganic minerals (oxides and sulfates), without any negative effect on productive performance.

Several studies have shown that complexed minerals have greater bioavailability than inorganic sources for laying hens (Świątkiewicz and Koreleski, 2008; Sun et al., 2012). Organic sources of $\mathrm{Cu}, \mathrm{Zn}$, and $\mathrm{Mn}$ improve egg shell quality in comparison with the inorganic sources (Klecher et al., 2002; Stefanello et al., 2014, Yenice et al., 2015).

The development of higher biological value sources alone is not enough to achieve the best genetic potential of modern laying hens. Adjusting the levels used according to the needs of the birds is more efficient than additional supplementation in high doses because the ratio of antagonism and synergism between trace minerals and the real needs of laying hens needs to be fully understood; thus, it is important that subsequent experiments be carried out to define these ideal levels. 
The benefits of genetic selection that have created the modern laying hen able to produce 500 eggs in a cycle that can reach 100 weeks, with improvement in laying persistence while maintaining egg quality and skeleton health, only reaches this objective when accompanied by the evolution of nutrition heavily adapted to the needs of the birds, not just production, but also the metabolic processes, in which microelements act directly and are essential (Bain et al., 2016).

The practical results of supplementing poultry diet with different minerals remain controversial, due to the differences between sources, levels used, chelation strength, and ligand minerals (House et al., 1997; Li et al., 2004). This has led to the pursuit of new studies to confirm the efficiency of different mineral sources to replace inorganic sources. Considering the foregoing, this work aimed to evaluate the performance and egg quality of Dekalb White layers receiving supplementation of a high biological value mineral, carbo-amino-phospho-chelates - CAPC (DSM, Nutritional Products, Brazil), compared with inorganic minerals in the form of sulfates, at different recommended values.

\section{Material and Methods}

This experiment was conducted in Areia, Paraíba, Brazil (06 57'48" S latitude and 3541'30" longitude West of Greenwich). Research on animals was conducted according to the institutional committee on animal use (case no. 148/2015). Three hundred and twenty birds of the Dekalb White breed were used, with 53 weeks of age in the beginning of the study, distributed in a completely randomized design between two treatments and 10 replicates of 16 birds each; the experimental period was 24 weeks. The diet was formulated based on corn and soybean meal according to the recommendations in the Dekalb White breed manual (Table 1).

The treatments used were: CAPC (DSM-recommended levels, $\mathrm{mg} / \mathrm{kg}$ ): $\mathrm{Cu}, 8.6 ; \mathrm{Fe}, 43.7 ; \mathrm{Mn}, 56.4 ; \mathrm{Se}, 0.34$; and $\mathrm{Zn}, 43.7$; and control - inorganic minerals (sulfate) (levels according to recommendation for the breed, $\mathrm{mg} / \mathrm{kg}$ ): $\mathrm{Cu}, 8$; Fe, 60; Mn, 70; Se, 0.25; and Zn, 60. The differences between formulated and analyzed levels are related to the minerals found in the diet ingredients (Table 2). As the availability of trace minerals in the ingredients is not known, they were not considered in the formulation of diets or experimental products.

The birds were housed in a conventional laying shed, covered with clay tile, with a trough-type feeder and a nipple drinker, grouped in galvanized wire cages measuring
$24 \times 37 \times 41 \mathrm{~cm}$. The experiment lasted 168 days, split into six periods of 28 days each, from August 2014 to February 2015.

The animal performance parameters were evaluated: feed intake (g/bird/day), egg production (\%), egg weight (g), egg mass (g), and feed conversion ratio by egg mass $(\mathrm{kg} / \mathrm{kg})$ and by dozen $(\mathrm{kg} /$ dozen $)$, and in the last three

Table 1 - Experimental diet

\begin{tabular}{lc}
\hline Ingredient & $\mathrm{g} / \mathrm{kg}$ as fed \\
\hline Corn $7.88 \%$ & 595.4 \\
Soybean meal $45 \%$ & 270.4 \\
Soybean oil & 13.8 \\
Limestone & 95.8 \\
Dicalcium phosphate & 16.5 \\
Salt & 4.0 \\
DL-methionine & 1.3 \\
Choline chloride & 0.7 \\
Vitamin mineral premix ${ }^{1,2}$ & 2.0 \\
Antioxidant ${ }^{3}$ & 0.1 \\
Total & 1000 \\
Chemical composition $(\mathrm{g} / \mathrm{kg}$ as fed) & \\
Metabolizable energy $(\mathrm{kcal} / \mathrm{kg})$ & \\
Crude protein & 2750 \\
Digestible methionine $+\mathrm{cystine}$ & 170.0 \\
Methionine & 6.10 \\
Digestible lysine & 3.69 \\
Calcium & 8.08 \\
Phosphorus & 41.00 \\
Chlorine & 4.31 \\
Potassium & 2.96 \\
Sodium & 6.67 \\
Linoleic acid & 1.75 \\
Electrolytic balance $(\mathrm{mEq} / \mathrm{kg})$ & 21.04 \\
\hline CAPC- & 163.00 \\
\hline
\end{tabular}

CAPC - carbo-amino-phospho-chelate.

${ }^{1}$ Tortuga Mineral and Vitamin premix per kg of product: folic acid, $500 \mathrm{mg}$; nicotinic acid, $15 \mathrm{~g}$; pantothenic acid, 4,000 mg; biotin, $50 \mathrm{mg}$; choline, $150 \mathrm{~g}$; vitamin $\mathrm{A}$, 4,000,000 IU; vitamin B1, 1,250 mg; vitamin B2, 2,500 mg; vitamin B6, 1,755 mg; vitamin $\mathrm{B} 12,7,500 \mu \mathrm{g}$; vitamin D3, 1,500,000 IU; vitamin E, 10,000 IU; vitamin $\mathrm{K} 3,1,250 \mathrm{mg}$; copper CAPC, 4,300 mg; iron CAPC, $21.85 \mathrm{~g}$; manganese CAPC, $28.20 \mathrm{~g}$; selenium CAPC, $170 \mathrm{mg}$; zinc CAPC, $21.85 \mathrm{~g}$; calcium iodate, $500 \mathrm{mg}$; phytase, 300,000 FYT.

${ }^{2}$ Inorganic Mineral and Vitamin premix per $\mathrm{kg}$ of product: folic acid, $500 \mathrm{mg}$ nicotinic acid, $15 \mathrm{~g}$; pantothenic acid, 4,000 mg; biotin, $50 \mathrm{mg}$; choline, $150 \mathrm{~g}$; vitamin A, 4,000,000 IU; vitamin B1, 1,250 mg; vitamin B2, 2,500 mg; vitamin B6, $1.755 \mathrm{mg}$; vitamin B12, 7,500 $\mu \mathrm{g}$; vitamin D3, 1,500,000 IU; vitamin E, 10,000 IU; vitamin $\mathrm{K} 3,1,250 \mathrm{mg}$; iron sulfate, $30 \mathrm{~g}$; manganese sulfate, $35 \mathrm{~g}$; zinc sulfate, $30 \mathrm{~g}$; copper sulphate, $4,000 \mathrm{mg}$; sodium selenite, $125 \mathrm{mg}$; calcium iodate, $500 \mathrm{mg}$; phytase, 300,000 FYT.

${ }^{3}$ Ethoxyquin.

Table 2 - Levels of formulated and analyzed trace minerals $(\mathrm{mg} / \mathrm{kg})$ in the different treatments

\begin{tabular}{lcccc}
\hline Trace mineral (mg/kg) & $\begin{array}{c}\text { CAPC } \\
\text { formulated }^{1}\end{array}$ & $\begin{array}{c}\text { CAPC } \\
\text { analyzed }^{2}\end{array}$ & $\begin{array}{c}\text { Sulfates } \\
\text { formulated }^{1}\end{array}$ & $\begin{array}{c}\text { Sulfates } \\
\text { analyzed }^{2}\end{array}$ \\
\hline Copper & 8.6 & 13.89 & 8 & 17.80 \\
Iron & 43.7 & 440.46 & 60 & 458.46 \\
Manganese & 56.4 & 78.69 & 70 & 99.23 \\
Zinc & 43.7 & 66 & 60 & 104.7 \\
\hline
\end{tabular}

CAPC - carbo-amino-phospho-chelate.

${ }^{1}$ Levels of formulated minerals (premix) in $\mathrm{mg} / \mathrm{kg}$ of diet

${ }^{2}$ Levels of analyzed minerals (feed) in $\mathrm{mg} / \mathrm{kg}$ of diet. 
days of each 28-day period, 10 eggs per replicate were used to evaluate egg quality variables (shell thickness, shell strength, weight and percentage of yolk, shell, and albumen, specific gravity, Haugh unit, and yolk color).

For the trace mineral concentration analysis, 60 eggs were collected per treatment at the end of the third period and dehydrated in the L101 model freeze-dryer. The trace minerals were analyzed, the samples were homogenized, weighed, subjected to digestion in acid medium under heat, dilution according to mineral content and calibration curve, and reading via inductively coupled plasma optical emission spectrometry (ICP-OES).

The quality of eggs stored at room temperature (shelf life) was analyzed at the end of the second experimental period (61 weeks old), when 30 eggs per replicate were selected and stored at room temperature $\left(25^{\circ} \mathrm{C}\right)$. In total, 300 eggs per treatment were observed and evaluated at 0 , $4,8,16$, and 21 days of storage for the variables: albumen weight and percentage, shell thickness, specific gravity, Haugh unit, and yolk color.

The variables were analyzed using the Statistical Analysis System computer program, version 9.4, an ANOVA analysis of variance was performed, and the means were compared by the $t$ test at $5 \%$ probability.

\section{Results}

Supplementation with CAPC was observed to increase $(\mathrm{P}<0.05)$ feed intake, egg weight, and egg mass compared with birds that received sulfate in the diet (Table 3).

Regarding mean weights of components and the internal and external quality of eggs from lightweight laying hens receiving supplementation of different trace mineral sources and recommendations, in the total experimental period (Table 4), the yolk weight, percentage of shell, and

Table 3 - Performance of lightweight laying hens from 53 to 77 weeks of age fed diet supplemented with different trace mineral sources and recommendations

\begin{tabular}{lcccc}
\hline \multirow{2}{*}{ Variable } & \multicolumn{3}{c}{ Source of mineral } & \\
\cline { 2 - 5 } & CAPC & Sulfate & & \\
\hline Feed intake (g/bird/day) & $114.62 \mathrm{a}$ & $112.30 \mathrm{~b}$ & 3.27 & 0.0014 \\
Egg production (\%) & 92.66 & 92.15 & 3.86 & 0.4397 \\
Weight of egg (g) & $65.69 \mathrm{a}$ & $64.93 \mathrm{~b}$ & 2.57 & 0.0166 \\
Egg mass (g) & $60.85 \mathrm{a}$ & $59.82 \mathrm{~b}$ & 4.06 & 0.0256 \\
$\begin{array}{l}\text { Feed conversion ratio per egg mass } \\
\text { (g/g) }\end{array}$ & 1.88 & 1.88 & 3.94 & 0.9016 \\
Feed conversion ration per dozen & 1.48 & 1.47 & 4.06 & 0.1631 \\
egg conversion (kg/dozen) & & & & \\
Eggs/housed bird & 25.48 & 25.17 & 2.33 & 0.2656 \\
\hline
\end{tabular}

CAPC - carbo-amino-phospho-chelate; $\mathrm{CV}$ - coefficient of variation.

Means in the same row followed by different letters differ $(\mathrm{P}<0.05)$ by the $t$ test. yolk color were influenced $(\mathrm{P}>0.05)$ by mineral sources. Supplementation with inorganic mineral only increased the percentage of yolk $(P=0.0040)$. Supplementation with CAPC increased albumen weight $(\mathrm{P}=0.0398)$, albumen percentage $(\mathrm{P}<0.0001)$, shell weight $(\mathrm{P}=0.0109)$, shell thickness $(\mathrm{P}=0.0012)$, shell strength $(\mathrm{P}<0.0001)$, and Haugh unit $(\mathrm{P}=0.0197)$.

The internal quality of eggs from hens fed CAPC, measured with the Haugh unit, was maintained higher in all evaluated weeks, except for experiment week 77 (Table 5). The same behavior occurred with external quality (shell), shell thickness (except week 57) (Table 6), and shell strength parameters in the evaluated periods (Table 7).

Birds receiving supplementation of CAPC had higher iron and zinc levels than birds receiving sulfate (Table 8), a response to the increased bioavailability of the CAPC source when compared with sulfates. For manganese, the

Table 4 - Weight of components and internal and external quality of eggs from lightweight laying hens between 53 and 77 weeks old fed diet supplemented with different trace mineral sources and recommendations

\begin{tabular}{lcccc}
\hline \multirow{2}{*}{ Variable } & \multicolumn{2}{c}{ Source of mineral } & & \\
\cline { 2 - 4 } & CAPC & Sulfate & & P-value \\
\hline Yolk weight (g) & 17.50 & 17.77 & 1.94 & 0.1036 \\
Albumen weight (g) & $41.99 \mathrm{a}$ & $41.03 \mathrm{~b}$ & 2.31 & 0.0398 \\
Shell weight (g) & $6.23 \mathrm{a}$ & $6.16 \mathrm{~b}$ & 1.42 & 0.0109 \\
Yolk percentage (\%) & $26.67 \mathrm{~b}$ & $27.36 \mathrm{a}$ & 2.51 & $<0.0001$ \\
Albumen percentage (\%) & $63.83 \mathrm{a}$ & $63.13 \mathrm{~b}$ & 1.41 & $<0.0001$ \\
Shell percentage (\%) & 9.33 & 9.32 & 4.24 & 0.8846 \\
Specific gravity (g/cm $\left.{ }^{3}\right)$ & $1.081 \mathrm{a}$ & $1.080 \mathrm{~b}$ & 0.20 & 0.0197 \\
Haugh unit & 92.10 & 90.39 & 6.66 & 0.1325 \\
Shell thickness (mm) & $423.19 \mathrm{a}$ & $412.73 \mathrm{~b}$ & 4.14 & 0.0012 \\
Yolk color & 6.53 & 6.38 & 8.23 & 0.1223 \\
Shell strength (kg/f) & $3.39 \mathrm{a}$ & $3.22 \mathrm{~b}$ & 4.19 & $<0.0001$ \\
\hline
\end{tabular}

CAPC - carbo-amino-phospho-chelate; CV - coefficient of variation.

Means in the same line followed by different letters differ $(\mathrm{P}<0.05)$ by the $\mathrm{t}$ test.

Table 5 - Haugh unit of eggs from laying hens fed diet supplemented with different trace mineral sources and recommendations over the course of the experimental periods (age of birds in weeks) and mean in the full period

\begin{tabular}{lcccc}
\hline \multicolumn{5}{c}{ Haugh unit } \\
\hline Period & Age (weeks) & CAPC & Sulfates & P-value \\
\hline 1 & 57 & 84.18 & 87.80 & $*$ \\
2 & 61 & 85.64 & 84.48 & $*$ \\
3 & 65 & 91.65 & 87.47 & $*$ \\
4 & 69 & 90.44 & 88.68 & $*$ \\
5 & 73 & 99.75 & 97.60 & $*$ \\
6 & 77 & 99.24 & 99.20 & NS \\
Mean & $57-77$ & 92.10 & 90.36 & $*$ \\
\hline
\end{tabular}

CAPC - carbo-amino-phospho-chelate; NS - not significant.

* Significant difference. 
result was the opposite. It is worth mentioning that, in addition to the source, the levels included in the diet were also different between the treatments.

The internal quality of eggs stored at room temperature remained higher in eggs from birds receiving minerals in the form of CAPC during all analyzed periods (Haugh unit) (Table 9). Better rates were observed for albumen percentage, shell thickness, and yolk color, when compared with eggs from birds supplemented with sulfates.

Table 6 - Shell thickness $(\mathrm{mm})$ of eggs from laying hens fed diet supplemented with different trace mineral sources and recommendations over the course of the experimental periods (age of birds in weeks) and mean in the full period

\begin{tabular}{lcccc}
\hline \multicolumn{5}{c}{ Shell thickness $(\mathrm{mm})$} \\
\hline Period & Age (weeks) & CAPC & Sulfates & P-value \\
\hline 1 & 57 & 430.79 & 433.90 & NS \\
2 & 61 & 443.88 & 435.01 & $*$ \\
3 & 65 & 434.79 & 417.24 & $*$ \\
4 & 69 & 418.30 & 400.32 & $*$ \\
5 & 73 & 409.45 & 400.95 & $*$ \\
6 & 77 & 401.95 & 388.95 & $*$ \\
Mean & $57-77$ & 423.19 & 412.73 & $*$ \\
\hline
\end{tabular}

CAPC - carbo-amino-phospho-chelate; NS - not significant.

* Significant difference.

Table 7 - Shell strength of eggs from laying hens fed diet supplemented with different trace mineral sources and recommendations over the course of the experimental periods (age of birds in weeks) and mean in the full period

\begin{tabular}{lcccc}
\hline \multicolumn{5}{c}{ Shell strength $(\mathrm{kg} / \mathrm{f})$} \\
\hline Period & Age (weeks) & CAPC & Sulfates & P-value \\
\hline 4 & 69 & 3.36 & 3.22 & $*$ \\
5 & 73 & 3.48 & 3.27 & $*$ \\
6 & 77 & 3.31 & 3.15 & $*$ \\
Mean & $69-77$ & 3.38 & 3.22 & $*$ \\
\hline
\end{tabular}

CAPC - carbo-amino-phospho-chelate.

* Significant difference.

Table 8 - Mineral content in eggs from birds fed diet supplemented with different trace mineral sources and recommendations

\begin{tabular}{lcccc}
\hline \multirow{2}{*}{ Treatment } & \multicolumn{4}{c}{ Minerals $(\mathrm{mg} / \mathrm{kg})$ in whole eggs } \\
\cline { 2 - 5 } & Copper & Iron & Manganese & Zinc \\
\hline CAPC & 5.08 & $83.89 \mathrm{a}$ & $2.59 \mathrm{~b}$ & $46.50 \mathrm{a}$ \\
Sulfates & 5.09 & $56.19 \mathrm{~b}$ & $3.61 \mathrm{a}$ & $32.75 \mathrm{~b}$ \\
CV $(\%)$ & 8.22 & 25.06 & 28.97 & 22.24 \\
P-value & 0.9231 & $<0.0001$ & 0.0009 & $<0.0001$ \\
\hline
\end{tabular}

CAPC - carbo-amino-phospho-chelate; CV - coefficient of variation.

Means in the same column followed by different letters differ $(\mathrm{P}<0.05)$ by the $t$ test.

\section{Discussion}

Similar results in relation to performance variables were reported in other studies comparing different sources of trace minerals to supplementation with inorganic sources (Fernandes et al., 2008; Świątkiewicz and Koreleski, 2008; Maciel et al., 2010).

Supplementation with CAPC increased the weight and albumen percentage in relation to the control diet using sulfates, and it maintained yolk weight throughout the experiment. On the other hand, eggs from birds receiving supplementation with the inorganic mineral source presented higher yolk percentage when compared with CAPC. This increase seen in yolk percentage may be related to the increased age of the birds. According to Carvalho (2012), eggs from older hens present higher total weight, higher yolk percentage and weight, and lower albumen and shell percentage.

A study conducted by Rutz et al. (2003) showed that supplementing layer diet with selenium, in a more available source, tended to show improvement in performance, yolk and albumen weight, as well as a consistent increase in albumen quality and improvement in yolk color, indicating a positive effect on the absorption and protection of seleniumsoluble substances. According to Gravena et al. (2011), organic selenium, in the form of selenium-methionine, influences egg quality, since it participates in the synthesis of proteins deposited in the albumen.

Shell quality is a critical point for the poultry industry because it influences the economic profitability of egg production and hatchability. Eggs that are more resistant to breakage and without defects on the shell are essential for protection against the penetration of pathogenic bacteria, such as Salmonella sp. (Świątkiewicz and Koreleski, 2008).

As a result of this experiment, by supplementing hen diet with CAPC, we obtained eggs with thicker shells and more resistant to breaking when compared with eggs from birds that received the inorganic mineral supplementation, and these qualities are maintained even with the advancing age of the birds. Similarly to Świątkiewicz and Koreleski (2008), Venglovská et al. (2014), Xiao et al. (2014, 2015), Mabe et al. (2003), and Stefanello et al. (2014), who studied different sources of trace minerals, we can affirm that minerals in the form of CAPC improve not only the strength, but also the shell thickness, egg component weights, and albumen quality.

The improvement in quality of laying hen eggs, especially in the variables related to shell, should be attributed primarily to the mineral source, which is the CAPC, because it was better utilized by the animals 
Table 9 - Quality of eggs stored, at room temperature, from birds fed diet supplemented with different trace mineral sources and recommendations

\begin{tabular}{|c|c|c|c|c|c|c|c|c|}
\hline & $\begin{array}{l}\text { Egg weight } \\
\text { (g) }\end{array}$ & $\begin{array}{l}\text { Shell thickness } \\
\qquad(\mathrm{mm})\end{array}$ & $\begin{array}{l}\text { Specific gravity } \\
\left(\mathrm{g} / \mathrm{cm}^{3}\right)\end{array}$ & Haugh unit & Yolk color & Yolk (\%) & Albumen (\%) & Shell (\%) \\
\hline \multicolumn{9}{|l|}{ Day 0} \\
\hline CAPC & 64.55 & $436.83 \mathrm{~A}$ & 1.082 & $90.20 \mathrm{~A}$ & 5.98 & 27.05 & 63.41 & 9.54 \\
\hline P-value & 0.6740 & $<0.0001$ & 0.5256 & $<0.0001$ & 0.6203 & 0.2277 & 0.1935 & 0.5551 \\
\hline $\mathrm{CV} \%$ & 3.42 & 1.93 & 0.22 & 2.58 & 6.05 & 2.73 & 1.35 & 4.00 \\
\hline \multicolumn{9}{|l|}{ Day 4} \\
\hline Sulfates & 64.49 & $403.82 \mathrm{~B}$ & $1.071 \mathrm{~B}$ & 78.67B & $5.25 \mathrm{~B}$ & $29.35 \mathrm{~A}$ & 60.96B & 9.69 \\
\hline P-value & 0.6102 & $<0.0001$ & 0.0080 & $<0.0001$ & 0.0038 & 0.0034 & 0.0144 & 0.9573 \\
\hline $\mathrm{CV} \%$ & 4.00 & 1.23 & 0.17 & 2.62 & 6.31 & 3.38 & 1.96 & 3.83 \\
\hline \multicolumn{9}{|l|}{ Day 8} \\
\hline CAPC & 62.45 & $423.94 \mathrm{~A}$ & 1.070 & $79.75 \mathrm{~A}$ & $5.72 \mathrm{~A}$ & 29.09B & $60.97 \mathrm{~A}$ & 9.94 \\
\hline \multicolumn{9}{|l|}{ Day 16} \\
\hline CAPC & 62.23 & 419.77A & 1.070 & $75.52 \mathrm{~A}$ & $6.37 \mathrm{~A}$ & 29.82 & $60.81 \mathrm{~A}$ & 9.88 \\
\hline Sulfates & 62.40 & 401.40B & 1.070 & $73.18 \mathrm{~B}$ & $6.08 \mathrm{~B}$ & 30.79 & $59.12 \mathrm{~B}$ & 10.10 \\
\hline P-value & 0.8625 & $<0.0001$ & . & 0.0455 & 0.0200 & 0.1107 & 0.0306 & 0.1000 \\
\hline $\mathrm{CV} \%$ & 3.41 & 1.58 & . & 3.27 & 3.98 & 4.29 & 2.69 & 2.74 \\
\hline \multicolumn{9}{|l|}{ Day 21} \\
\hline CAPC & 61.03 & $424.34 \mathrm{~A}$ & 1.070 & $58.55 \mathrm{~A}$ & 5.90 & 31.33 & 58.35 & 10.32 \\
\hline Sulfates & 61.52 & 409.37B & 1.070 & $54.76 \mathrm{~B}$ & 5.83 & 31.37 & 58.24 & 10.40 \\
\hline P-value & 0.5766 & $<0.0001$ & . & 0.0075 & 0.6009 & 0.9448 & 0.8626 & 0.6340 \\
\hline CV\% & 3.10 & 0.78 & . & 4.97 & 4.87 & 4.37 & 2.49 & 3.30 \\
\hline
\end{tabular}

CAPC - carbo-amino-phospho-chelate; $\mathrm{CV}$ - coefficient of variation.

Means in the same column followed by different letters differ $(\mathrm{P}<0.05)$ by the $t$ test.

compared with the inorganic source, bringing benefits to the bird diets. Additionally, the importance of some minerals found in the evaluated product should be underscored. These minerals may affect egg quality because they have catalytic properties, acting on key enzymes involved in the membrane and egg shell formation process, or by interacting directly with the calcite crystals (Mabe et al., 2003).

One of the minerals present in CAPC is manganese, which has an influence on synthesis of the egg internal and external membranes, granting greater resistance to breaking. This mineral acts as an activator of the enzyme glycosyltransferase in the synthesis of glycosaminoglycans and glycoproteins, which contribute to formation of the organic matrix of the egg (Stefanello et al., 2014).

According to Świątkiewicz et al. (2014), zinc is important for shell synthesis because it is a cofactor of carbonic anhydrase, an enzyme that forms calcium and phosphorus crystals and contributes to calcium fixation in the form of calcium carbonate in the eggs, and it improves strength when combined with manganese.
Regarding copper, its role in egg shell formation has not been fully elucidated, but we know that there is a high concentration of this mineral in the isthmus, where the eggshell is formed (Vicenzi, 1996). It is also an integral part of the enzyme lysyl oxidase, which is important in the formation of collagen found in the eggshell membrane (Świątkiewicz et al., 2014).

Thus, according to Stefanello et al. (2014), zinc, manganese, and copper can positively modify the eggshell properties by the formation of calcite crystals, in addition to altering the crystal structure of the eggshell. We can, therefore, associate all positive egg quality effects with the supplementation with more available source minerals.

According to Mabe et al. (2003), when supplementing birds with trace minerals from more available sources and inorganic source, an increase in the concentration of zinc and manganese in the yolk was observed for the most available source, while copper concentration was unaffected. In the study by Skrivan et al. (2005), there was an increase in iron concentration in the yolk when hens fed diets supplemented with more available 
minerals, either combined or individually. Such results were also observed in the study by Bittencourt et al. (2011), in which eggs from birds that received CAPC in the diet had higher iron deposition.

The study by Bahakaim et al. (2014) demonstrated that birds fed diet supplemented with zinc-methionine presented higher values of this mineral when compared with the inorganic source. According to the same author, this increase may have occurred due to the higher bioavailability of the source. Kim and Patterson (2005) and Plaimast et al. (2008) observed an increase in zinc deposition in the egg linearly with the diet levels. The increased zinc in the egg was probably due to the increased production of vitellogenin, the glycoprotein carrier of this trace mineral from the liver to the egg yolk.

The shelf-life test variable results matched the study by Pappas et al. (2005), which confirmed that mineral supplementation can attenuate the Haugh unit reduction in stored eggs. Franco and Sakamoto (2005) also found that layers fed diets supplemented with selenium, zinc, and manganese bound to organic molecules maintained internal egg quality during the storage period at room temperature and in the refrigerator.

During the storage period, a decrease in egg and albumen weights and albumen percentage was observed, and conversely, an increase in yolk weight and yolk and shell percentage, which is associated with the decreased water in the albumen. This reduction is associated with the intense loss of $\mathrm{CO}_{2}$ and water to the medium through the shell, due to storage temperature, storage period, relative humidity, and porosity of the shell (Pombo, 2003; Moura et al., 2008; Santos et al., 2009; Freitas et al., 2011). Moreover, according to Gonzales and De Blas (1991), when the egg is subjected to storage, physical and chemical reactions occur, which can degrade the protein structures found in the albumen; such reactions lead to the water associated with large protein molecules that pass into the yolk through osmosis. This excess water increases the size of the yolk and weakens the vitelline membrane, making it appear flatter when broken on a flat surface. With aging of the egg, the vitelline membrane of the yolk becomes more permeable, allowing moisture from the albumen to be incorporated into the yolk, increasing its size (Kirunda and Mckee, 2000).

The reduction in Haugh unit values is related to the reduction in albumen height with storage days. According to Albino (2014), the chemical changes during storage that cause a decrease in albumen height are unclear, but there may be several causes, and some are attributed to ovomucin proteolysis, cleavage of disulfide bridges, and the interactions between $\alpha$ and $\beta$ ovomucins. According to Sun et al. (2012), the effects of copper and chelated zinc in their study may have diminished the dissociation of ovomucin-lysozyme, a compound that maintains the integrity of albumen viscosity.

According to Franco and Sakamoto (2005), supplementation with organic selenium may allow the maintenance of the internal quality of the egg, especially in storage periods, justifying the improvement in albumen quality observed in this study. Some studies have shown that trace minerals of higher biological value, such as zinc, manganese, and selenium, are transferred more efficiently to the egg when compared with inorganic sources, and in the case of selenium, it is mainly deposited in the albumen, while the selenium from the inorganic source is transferred to the yolk (Latshaw and Osman, 1975; Miles, 2000). Thus, selenium can improve albumen consistency, extending the shelf life period (Pan et al., 2010).

Eggs from laying hens that received mineral supplementation in the form of CAPC had thicker shells during storage days. This may have been due to the fact that compound trace minerals have a higher bioavailability when compared with the inorganic source, and at the time of eggshell formation, zinc, manganese, and copper, active participants in this process, were more absorbed, consequently leading to thicker shells from the beginning of the storage period.

The egg quality offered to the consumer has increased consumption of this product and the use of its nutritional advantages by the population. This is due to a set of characteristics that influence the degree of acceptance in the market. Egg is considered a perishable food, and it starts losing internal quality as soon as it is laid. As such, proper measures must be taken for its preservation, considering that loss of quality is an inevitable phenomenon that happens gradually over time and can be aggravated by several factors (Barbosa et al., 2008).

The increase in concentration of trace minerals that can act by reducing the oxidative process by antioxidant action and which improve shell quality by reducing the gas exchanges only slow this natural process in storage.

\section{Conclusions}

Total replacement of the sulfate source of trace minerals for another of higher biological value (carboamino-phospho-chelates) has little influence on the performance of birds, and levels can be adjusted without harming production. On the other hand, carbo-aminophospho-chelate contributes to better egg shell formation, 
albumen quality, and nutritional value, thus representing a benefit to the producer because they will have more resistant and fresher eggs in the production, transport, and storage process.

\section{References}

Albino, L. F. T. 2014. Galinhas poedeiras: Criação e alimentação. Aprenda Fácil, Viçosa, MG.

Bahakaim, A. S. A.; Hmat, A. A. M.; Sahar, M. H. O.; Amal, S. O.; Abdelmalak, N. Y. and Ehad, A. R. 2014. Effect of using different levels and sources of zinc in Layer's diets on egg zinc enrichment. Egypt Poultry Science 34:39-56. https://doi.org/10.21608/epsj.2014.5305

Bain, M. M.; Nys Y. and Dunn, I. C. 2016. Increasing persistency in lay and stabilising egg quality in longer laying cycles: What are the challenges? British Poultry Science 57:330-338. https://doi.org/10.1080/00071668.2016.1161727

Barbosa, N. A. A.; Sakomura, N. K.; Mendonça, M. O.; Freitas, E. R. and Fernandes, J. B. K. 2008. Qualidade de ovos comerciais provenientes de poedeiras comerciais armazenados sob diferentes tempos e condições de ambientes. Ars Veterinaria 24:127-133.

Bittencourt, L. C.; Sechinato, A. S. and Tamassia, L. F. M. 2011. Bioaccumulation of iron, copper, zinc and manganese in eggs of layer hens. In: Anais do $22^{\circ}$ Congresso Brasileiro de Avicultura, São Paulo, SP.

Carvalho, L. S. S. 2012. Desempenho produtivo e qualidade de ovos de galinhas poedeiras em segundo ciclo de postura alimentadas com minerais orgânicos. Dissertação (M.Sc.). Universidade Federal de Uberlândia, Uberlândia, MG.

Fernandes, J. I. M.; Murakami, A. E.; Sakamoto, M. I.; Souza, L. M. G.; Malaguido, A. and Martins, E. N. 2008. Effects of organic mineral dietary supplementation on production performance and egg quality of white layers. Brazilian Journal of Poultry Science 10:59-65. https://doi.org/10.1590/S1516-635X2008000100009

Franco, J. R. G. and Sakamoto, M. I. 2005. Qualidade de ovos: Uma visão geral dos fatores que a influenciam. Ave World, São Paulo, SP.

Freitas, L. W.; Paz, I. C. L. A; Garcia, R. G.; Caldara, F. R.; Seno, L. O.; Felix, G. A.; Lima, N. D. S.; Ferreira, V. M. O. S. and Cavichiolo, F. 2011. Aspectos qualitativos de ovos comerciais submetidos a diferentes condições de armazenamento. Revista Agrarian 4:66-72.

Gonzales, M. and Blas, B. C. 1991. Nutricion y alimentacion de gallinas ponedoras. Mundi-Prensa, Madrid.

Gravena, R. A.; Marques, R. H.; Roccon, J.; Picarelli, J.; Hada, F. H.; Silva, J. D. T.; Queiroz, S. A. and Moraes, V. M. B. 2011. Egg quality during storage and deposition of minerals in eggs from quails fed diets supplemented with organic selenium, zinc and manganese. Revista Brasileira de Zootecnia 40:2767-2775. https://doi.org/10.1590/S1516-35982011001200022

House, W. A.; VanCampen, D. R. and Welch, R. M. 1997. Dietary methionine status and its relation to the bioavailability to rats of zinc in corn kernels with varying methionine content. Nutrition Research 17:65-76. https://doi.org/10.1016/S0271-5317(96)00233-3

Kim, K. W. and Patterson, P. H. 2005. Effects of dietary zinc supplementation on hen performance, ammonia volatilization, and nitrogen retention in manure. Journal of Environmental Science and Health 40:675-686. https://doi.org/10.1081/PFC-200061598

Kirunda, D. F. K and Mckee, S. R. 2000. Relating quality characteristics of aged eggs and fresh eggs to vitelline membrane strength as determined by a texture analyzer. Poultry Science 79:1189-1193. https://doi.org/10.1093/ps/79.8.1189
Klecker, D.; Zeman, L.; Jelinek, P. and Bunesova, A. 2002. Effect of manganese and zinc chelates on the quality of eggs. Acta Universitatis Agriculturae et Sylviculturae Mendelianae Brunensis 50:59-68.

Latshaw, J. D. and Osman, M. 1975. Distribution of selenium in egg white and yolk after feeding natural and synthetic selenium compounds. Poultry Science 54:1244-1252. https://doi.org/10.3382/ps.0541244

Li, S. F.; Luo, X. G.; Crenshaw, T. D.; Liu, B.; Kuang, X. and Yu, S. 2004. Use of chemical characteristics to predict the relative bioavailability of supplemental organic manganese sources for broilers. Journal of Animal Science 82:2352-2363. https://doi.org/10.2527/2004.8282352x

Mabe, E. I.; Rapp, C.; Bain, M. M. and Nys, Y. 2003. Supplementation of a corn-soybean meal diet with manganese, copper, and zinc from organic or inorganic sources improves eggshell quality in aged laying hens. Poultry Science 82:1903-1913. https://doi.org/10.1093/ps/82.12.1903

Maciel, M. P.; Saraiva E. P.; Aguiar, E. F.; Ribeiro, P. A.; Passos, D. P. and Silva, J. B. 2010. Effect of using organic microminerals on performance and external quality of eggs of commercial laying hens at the end of laying. Revista Brasileira de Zootecnia 39:344-348. https://doi.org/10.1590/S1516-35982010000200017

Miles, R. D. 2000. Trace minerals and avian embryo development. Ciência Animal Brasileira 2:1-10.

Mohanna, C. and Nys, Y. 1997. Excess zinc in manure of broiler chicks: decrease in zinc supplementation and use of phytase improve its retention in the carcass. p.459-461. In: Proceedings of the 11th European Symposium on Poultry Nutrition, Faaborg.

Moura, A. M. A.; Oliveira, N. T. E.; Thiebaut, J. T. L. and Melo, T. V. 2008. Efeito da temperatura de estocagem e do tipo de embalagem sobre a qualidade interna de ovos de codornas japonesas (Coturnix japonica). Ciência e Agrotecnologia 32:578-583. https://doi.org/10.1590/S1413-70542008000200036

Pan, E. A.; Rutz, F.; Dionello, N. J. L.; Anciuti, M. and Krabbe, E. L. 2010. Desempenho de poedeiras semipesadas arraçoadas com suplementação de selênio orgânico. Revista Brasileira Agrociências 16:83-89.

Pappas, A. C.; Acamovic, T.; Sparks, N. H. C.; Surai, P. F. and McDevitt, R. M. 2005. Effects of supplementing broiler breeder diets with organic selenium and polyunsaturated fatty acids on egg quality during storage. Poultry Science 84:865-874. https://doi.org/10.1093/ps/84.6.865

Plaimast, H.; Sirchakwal, P.; Puwastien, P. and Kijparkorn, S. 2008. Effect of supplementary zinc from organic and inorganic sources on laying performance and zinc deposition in eggs. The Thai Journal of Veterinary Medicine 38:47-53.

Pombo, C. R. 2003. Efeito do tratamento térmico de ovos inteiros na perda de peso e características de qualidade interna. Rio de Janeiro. Dissertação (M. Sc.). Universidade Federal Fluminense, Rio de Janeiro, RJ.

Rutz, F.; Pan, E. A.; Xavier, E. G. and Anciuti, M. A. 2003. Meeting selenium demands of modern poultry: responses to Sel-Plex ${ }^{\mathrm{TM}}$ organic selenium in broiler and breeder diets. p.147-161. In: Nutritional biotechnology in the feed and food industries. Proceedings of Alltech's 19th Annual Symposium. Nottingham University Press, Nottingham.

Santos, M. S. V.; Espindola, G. B.; Lobo, R. N. B.; Freitas, E. R.; Guerra, J. L. L. and Santos, A. B. E. 2009. Efeito da temperatura e estocagem em ovos. Ciência e Tecnologia de Alimentos 29:513-517.

Skrivan, M.; Skrivanova, V. and Marounek, M. 2005. Effects of dietary zinc, iron, and copper in layer feed on distribution of these elements in eggs, liver, excreta, soil, and herbage. Poultry Science $84: 1570-1575$. 
Stefanello, C.; Santos, T. C.; Murakami, A. E.; Martins, E. M. and Carneiro, T. C. 2014. Productive performance, eggshell quality, and eggshell ultrastructure of laying hens fed diets supplemented with organic trace minerals. World's Poultry Science Journal 93:104-113. https://doi.org/10.3382/ps.2013-03190

Sun, Q.; Guo, Y.; Li, J.; Zhang, T. and Wen, J. 2012. Effects of methionine hydroxy analog chelated $\mathrm{Cu} / \mathrm{Mn} / \mathrm{Zn}$ on laying performance, egg quality, enzyme activity and mineral retention of laying hens. Japan Poultry Science Association 49:20-25. https://doi.org/10.2141/jpsa.011055

Świątkiewicz, S. and Koreleski, J. 2008. The effect of zinc and manganese source in the diet for laying hens on eggshell and bones quality. Veterinarni Medicina 53:555-563. https://doi.org/10.17221/1966-VETMED

Świątkiewicz, S.; Arczewska-Włosek, A. and Józefiak, D. 2014. The efficacy of organic minerals in poultry nutrition: review and implications of recent studies. World's Poultry Science Journal 70:475-486. https://doi.org/10.1017/S0043933914000531

Venglovská, K.; Gresáková, L.; Plachá, I.; Ryzner, M. and Cobanová, K. 2014. Effects of feed supplementation with manganese from its different sources on performance and egg parameters of laying hen. Czech Journal Animal Science 59:147-155.

Vicenzi, E. 1996. Fadiga de gaiola e qualidade da casca do ovo: aspectos nutricionais. p.77-91. In: Anais do $6^{\circ}$ Simpósio Técnico de Produção de Ovos. Associação Paulista de Avicultura, São Paulo, SP.

Xiao, J. F.; Zhang, Y. N.; Wu, S. G.; Zhang, H. J.; Yue, H. Y. and Qi, G. H. 2014. Manganese supplementation enhances the synthesis of glycosaminoglycan in eggshell membrane: a strategy to improve eggshell quality in laying hens. Poultry Science 93:380-388. https://doi.org/10.3382/ps.2013-03354

Xiao, J. F.; Wu, S. G.; Zhang, H. J.; Yue, H. I.; Wang, J.; Ji, F. and Qi, G. H. 2015. Bioefficacy comparison of organic manganese with inorganic manganese for eggshell quality in Hy-Line Brown laying hens. Poultry Science 94:1871-1878. https://doi.org/10.3382/ps/pev138

Yenice, E.; Mizrak, C.; Gültekin, M.; Atik, Z. and Tunca, M. 2015. Effects of organic and inorganic forms of manganese, zinc, copper, and chromium on bioavailability of these minerals and calcium in late-phase laying hens. Biological Trace Element Research 167:300-307. https://doi.org/10.1007/s12011-015-0313-8 